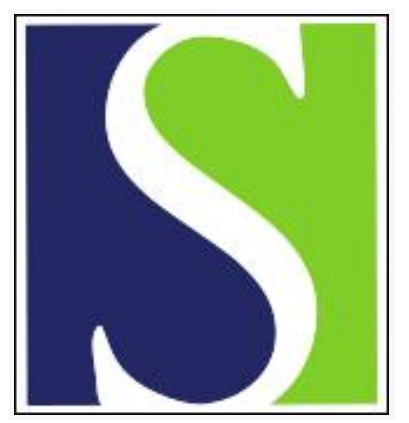

Scand J Work Environ Health 2005;31(5):329-335

https://doi.org/10.5271/sjweh.915

Issue date: Oct 2005

Long workhours, work scheduling and work-related injuries among construction workers in the United States

by Dong $X$

Affiliation: The Center to Protect Workers' Rights, Silver Spring, Maryland 20910, USA. SDong@cpwr.com

The following articles refer to this text: 2006;32(6):421-430;

2006;32(6):502-514; 2007;33(1):37-44; 2008;34(3):213-223;

2011;37(3):173-185; 2017;43(6):578-586; 2018;44(4):341-350;

2018;44(4):335-339; 2020;46(5):480-487; 2020;46(6):570-578

Key terms: construction worker; ending worktime; long workhours; longitudinal survey; multiple jobs; overtime; shift work; starting worktime; United States; work scheduling; work-related injury; worker safety

This article in PubMed: www.ncbi.nlm.nih.gov/pubmed/16273958 


\title{
Long workhours, work scheduling and work-related injuries among construction workers in the United States
}

\author{
by Xiuwen Dong, $\mathrm{MSc}^{1}$
}

\begin{abstract}
Dong X. Long workhours, work scheduling and work-related injuries among construction workers in the United States. Scand J Work Environ Health 2005;31(5):329-335.

Objectives The objectives of this study were (i) to examine work scheduling in construction and (ii) to establish whether there is any connection between workhours and safety outcomes among construction workers.

Methods The National Longitudinal Survey of Youth, 1979 cohort (NLSY79), was used for the data analysis. Odds ratios were used to measure the risk of work-related injury in different worker groups.

Results The findings showed that (i) construction workers started work earlier, worked longer days and fewer weeks a year, and were more likely to hold multiple jobs and change jobs than their nonconstruction counterparts and (ii) long workhours and irregular work schedules were significantly associated with a higher work-related injury rate after control for possible confounders.
\end{abstract}

Conclusion The results provide evidence that overtime and irregular work scheduling have an adverse effect on worker safety.

Key terms ending worktime; long workhours; longitudinal survey; multiple jobs; overtime; shift work; scheduling; starting worktime; work-related injury; worker safety.

Work scheduling variables such as work-rest schedules, weekly duration of work, shift work, and extended periods of overtime presumably relate to worker fatigue, hazard exposures, cumulative trauma, and other health outcomes (1). Much of the research on the relation between workhours and health has focused on shift work (25). Duchon \& Smith (6) reviewed laboratory, field, and accident analyses of extended hours (regular shift lengths of 10 or 12 hours, while still maintaining a 40-hour workweek) and safety and found that the results were so various that they could not draw general conclusions.

In recent years, the connection between long workhours and health has been attracting growing interest. Studies have found effects of long workhours on psychological well-being and mental health, insufficient sleep, and an increase in blood pressure, cholesterol concentrations, and substance abuse (7-11). Unhealthy weight gain, musculoskeletal problems, cumulative trauma disorders, fatigue, and mortality have also been reported as associated with long workhours (12-19). Van Der Hulst reviewed 27 recent empirical studies, obtaining more evidence on long workhours and adverse health. However, the evidence is inconclusive because many studies did not control for potential confounders (20). Despite the fact that the number of published studies examining long workhours appears to be increasing, a recent report by the National Institute for Occupational Safety and Health in the United States shows that few studies have examined how the number of hours worked per week, shift work, shift length, the degree of control over one's work schedule, and other characteristics of work schedules interact and relate to safety and health (21).

Construction workers face rapidly changing workplaces, a high degree of competition, and bouts of unemployment, as well as vast amounts of overtime (22, 23). The use of overtime is the most common means of speeding up projects that are schedule-driven and of replacing labor when shortages occur. Pressures and fatigue related to overtime may affect workers' ability to remain safe in the workplace; yet little has been documented about the effects of overtime and work schedules on construction workers' safety. Analyzing workers' compensation claims and payroll data for over 2800 contracts on a large construction project, Lowery et al (24) found that the risk for total and nonlost-worktime injuries was elevated for contracts with overtime payrolls greater than $20 \%$. Similarly, in five focus group discussions with construction workers, Goldenhar et al (25) found overtime to be associated with several

1 The Center to Protect Workers' Rights, Silver Spring, Maryland, United States.

Reprint requests to: Xiuwen Dong, The Center to Protect Workers' Rights, 8484 Georgia Avenue, Suite 1000, Silver Spring, MD 20910, USA. [E-mail: SDong@cpwr.com] 
adverse health and safety outcomes, including sleep deprivation, injury, fatigue, and stress. Nevertheless, the generalizability of the two studies is limited because of the study samples.

The primary purpose of this study was to characterize workhours and work schedules for a nationally representative cohort of construction workers in the United States (US) and identify any association between long workhours or work schedules and worker safety among this group. The hypotheses of this study were (i) work schedules of construction workers differ from those of workers in other industries and (ii) the risk of work-related injury increases as workhours increase. There were two concerns in terms of worker safety with respect to overtime work. The first related to fatigue and its influence on behavior associated with safe work practices, such as paying attention to safety and being willing to take potentially risky shortcuts. The second related to prolonged exposure to physical, chemical, and other hazards; however, the survey provided only limited information on the work environment.

\section{Study population and methods}

\section{Data and sample size}

This study analyzed data from the National Longitudinal Survey of Youth, 1979 cohort (NLSY79) from 1992 through 1998. NLSY79 is a nationally representative survey sponsored by the US Bureau of Labor Statistics and conducted by the Ohio State University. The survey was based on a national sample of 12686 men and women whose ages ranged from 14 through 21 years as of 1 January 1979, when the survey began. These persons were interviewed annually from 1979 through 1994, and biannually starting in 1996. The NLSY provides detailed information on demographics, work history, socioeconomic characteristics, and a variety of health questions. Beginning with the 1988 survey, an extensive series of questions was initiated on work-related injuries and illnesses. The respondent is asked specifically for the most recent and most severe work injury. This information facilitated the tracking of work histories for the respondents and the establishment of any relationship between workhours and work-related injuries in the present study.

In each survey, 550 to 600 respondents reported that their main job (in any occupation) was in the construction industry, codes 067-077 in the 1970 US Census Industrial Classification (26); the respondents employed in other industries were defined as nonconstruction workers $(\mathrm{N} \approx 7000$ per survey). Altogether 2584 construction-related observations were compiled during the study period. Production (blue-collar) workers were coded $401-575$ and $601-785$ by the 1970 US Census Occupational Classification. The variables used for this study were selected from NLSY79's Main and Work History files of the 1992-1998 surveys, linked by the survey identification number.

\section{Definition and measurement}

Workhours. The NLSY79 collected information on the number of workhours that a respondent worked at all jobs during the survey week, the number of workhours per day and per week on each job, and the usual hours worked per day or per week. Two summary variables created for each year provided information on the total number of hours that a respondent worked. One was how many weeks worked, and the other was how many hours worked since the previous interview. These workhour variables were used to estimate the hours worked by an individual worker. Overtime was defined as working $>8$ hours per day and $>40$ hours per week.

Work-related injuries. The NLSY respondents were asked "Since [date of last interview], have you had an incident at any job that resulted in an injury or illness to you?" In the following questions, the respondents were asked whether the result was an injury or an illness and whether it was the MOST SEVERE injury or illness since the date of the previous interview. Because very few incidents resulted in illness in construction and most construction injuries were reported as severe injuries, the data analysis focused on severe injuries in this study. In addition, to calculate injury rates in a 2-year period (since the last interview), only the 1996 and 1998 surveys were used for the injury-related analyses.

\section{Statistical methods}

The t-test and the chi-square test were used to identify the difference in workhours and work schedules between the construction and nonconstruction workers and the difference in the injury rates for workers with various workhours and work schedules. To test the interaction between overtime and work schedules (workshifts, time to start and end work) in relation to work-related injuries, the SAS GLM (general linear model) procedure (SAS Insitute, Cary, NC, USA) was used. Built on descriptive statistics and the GLM results, a multiple logistic regression model was developed to evaluate the association between long workhours and worker safety after control for possible confounders. To better estimate the overtime effects on the safety of production workers, the respondents in service and white-collar occupations and those who usually worked $<7$ hours a day were excluded from the GLM and logistic regression model. 
In addition, all statistics in this paper were weighted by NLSY population weights to reflect the initial sampling design, which involved an oversampling of blacks and differential attrition. The level of statistical significance was set at $\mathrm{P}<0.05$. SAS version 9.1 was used for the statistical analyses.

\section{Results}

\section{Worker characteristics}

Most of the respondents employed in the construction industry were male; only $8 \%$ were female. Two-thirds $(67 \%)$ of these respondents worked in special trade construction, $20 \%$ was employed as general building contractors, $10 \%$ was in heavy construction, and for the rest, the sector was not specified. Approximately $78 \%$ ( $N=2100$ in five surveys) of the construction workers were in production occupations, including carpenter, electrician, roofer, construction laborer, helper, and other construction trades. Within these occupations, African-American workers accounted for 10\%, 6\% were Hispanic, and only $4 \%$ were female. In other industries, $26 \%$ ( $\mathrm{N}=8740$ in five surveys) were production workers, of which $18 \%$ were African-American, $7 \%$ were
Hispanic, and $23 \%$ were female. In addition, more than $20 \%$ of the construction workers reported they were self-employed, whereas the corresponding proportion was $10 \%$ in other industries.

\section{Work schedules and workhours}

Overall, construction workers started work earlier in the morning than did other workers. About $63 \%$ began work between 0600 and 0700 , while $30 \%$ of the nonconstruction workers started work that early (figure 1). Most of the construction workers (65\%) ended work between 1530 and 1700, and less than $7 \%$ ended work at or after 1900; for nonconstruction workers, including those who did shift work, 14\% ended work at or after 1900 (figure 2).

Approximately $42 \%$ of the construction workers reported that they usually worked $>8$ hours per day compared with $31 \%$ of the workers in other industries (table 1). Nearly $90 \%$ of the construction workers worked a regular day shift, while $64 \%$ of the workers in nonconstruction industries did. Compared with workers in other industries, construction workers were generally more likely to change jobs and hold more than one job and less likely to have a full-time job and flexible work schedules (table 1). Construction workers worked more hours per week, but fewer weeks per year than their
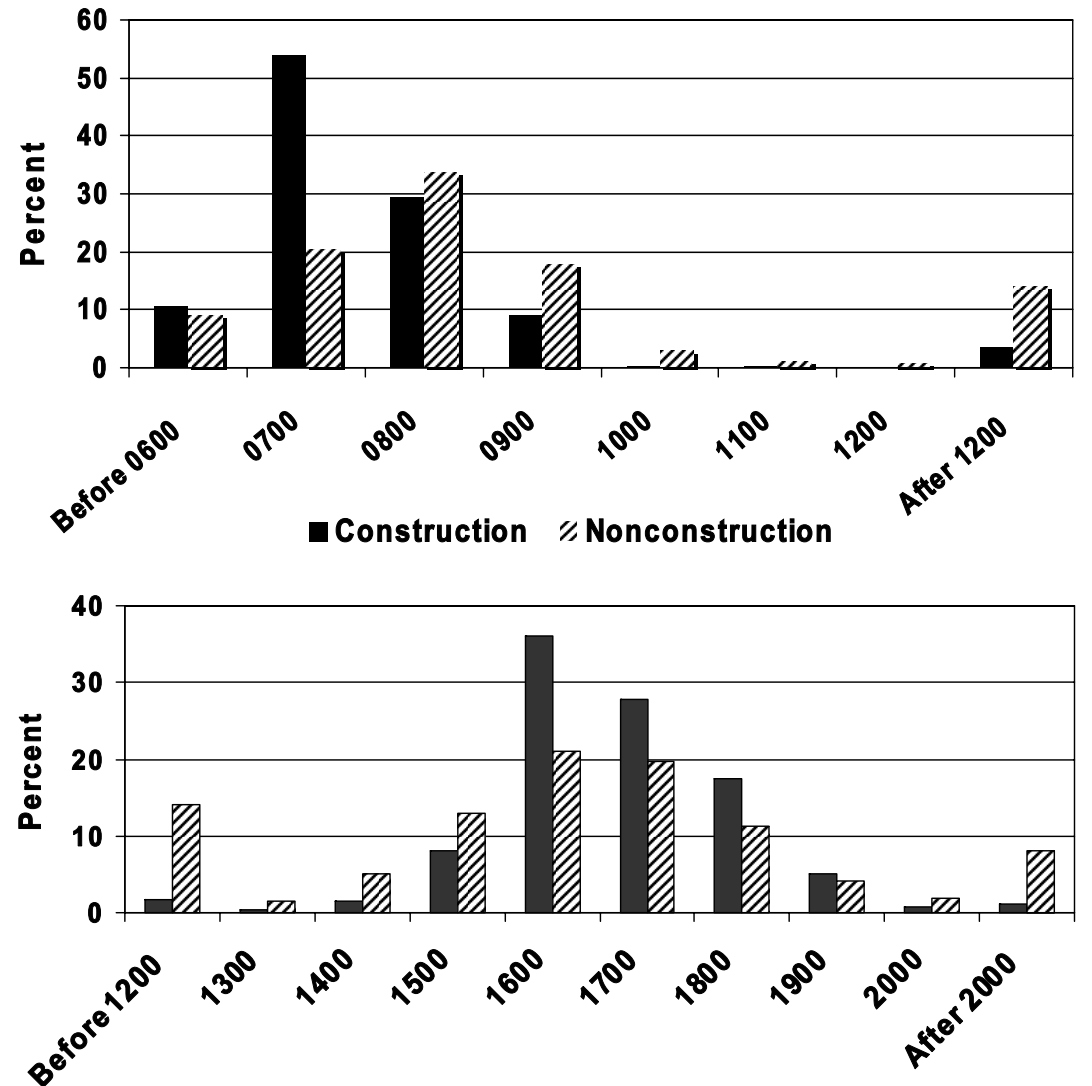

$\square$ Construction $\square$ Nonconstruction
Figure 1. Time of day workers usually began work in their main job (production occupations; $\mathrm{N}=2100$ in construction, 8740 in nonconstruction).

Figure 2. Time of day workers usually ended work in their main job (production occupations; $\mathrm{N}=2100$ in construction, 8740 in nonconstruction). 
Table 1. Work schedules, construction versus nonconstruction (production occupations).

\begin{tabular}{lcc}
\hline Characteristics & $\begin{array}{c}\text { Construction } \\
(\mathrm{N}=2100)(\%)\end{array}$ & $\begin{array}{c}\text { Nonconstruction } \\
(\mathrm{N}=8740)(\%)\end{array}$ \\
\hline Usual workhours per day & & \\
1-6 hours & 3.0 & 13.0 \\
$7-8$ hours & 54.7 & 55.4 \\
-10 hours & 34.4 & 21.4 \\
11-12 hours & 6.5 & 7.1 \\
13-14 hours & 0.1 & 1.3 \\
$\geq 15$ hours & 1.1 & 1.5 \\
Shift work & & \\
Regular day shift & 89.5 & 64.3 \\
Regular evening shift & 0.2 & 8.9 \\
Regular night shift & 0.7 & 7.3 \\
Rotating shift & 1.9 & 6.6 \\
Split shift & 0.4 & 1.7 \\
Irregular schedule or hours & 6.5 & 9.8 \\
Other & 0.9 & 1.4 \\
Flexible work schedule & 36.4 & 42.6 \\
Usually worked at main job & 90.8 & 97.8 \\
More than one job & 37.3 & 25.5 \\
Less than full-time & 35.9 & 18.8 \\
Changed job since last interview & 40.0 & 27.0 \\
\hline
\end{tabular}

Table 2. Workhours and related characteristics, construction $(\mathrm{N}=2100)$ versus nonconstruction $(\mathrm{N}=8740)$ (production occupations). ( $95 \% \mathrm{Cl}=95 \%$ confidence interval)

\begin{tabular}{|c|c|c|c|c|c|}
\hline Variable & $\begin{array}{l}\text { Cons- } \\
\text { truc- } \\
\text { tion }\end{array}$ & $\begin{array}{l}\text { Non- } \\
\text { cons- } \\
\text { truction }\end{array}$ & $\begin{array}{l}\text { Differ- } \\
\text { ence }\end{array}$ & $95 \% \mathrm{Cl}$ & P-value \\
\hline Hours per day & 8.8 & 8.3 & 0.5 & $0.25-0.70$ & $<0.01$ \\
\hline Hours per week & 44.3 & 40.6 & 3.8 & $2.45-5.08$ & $<0.01$ \\
\hline $\begin{array}{l}\text { Hours of overtime } \\
\text { last week }{ }^{\text {a }}\end{array}$ & 13.2 & 9.6 & 3.6 & $1.34-3.78$ & $<0.01$ \\
\hline Weeks per year & 42.6 & 44.6 & -1.9 & $-2.71--1.18$ & $<0.01$ \\
\hline Hours per year & 2033.5 & 1923.3 & 110.2 & $16.22-204.20$ & 0.02 \\
\hline $\begin{array}{l}\text { Hours since last } \\
\text { interview }{ }^{b}\end{array}$ & 4011.4 & 3732.7 & 278.7 & $74.82-482.60$ & 0.01 \\
\hline $\begin{array}{l}\text { Unemployed weeks } \\
\text { (per year) }\end{array}$ & 3.7 & 2.3 & 1.4 & $0.88-1.87$ & $<0.01$ \\
\hline $\begin{array}{l}\text { Unemployed weeks } \\
\text { since last interview }^{b}\end{array}$ & 5.3 & 3.5 & 1.8 & $0.61-2.95$ & $<0.01$ \\
\hline Mileage & 12.1 & 8.3 & 3.8 & $0.94-6.56$ & $<0.01$ \\
\hline Travel time (minutes) & 21.0 & 16.9 & 4.1 & $0.74-7.36$ & $<0.01$ \\
\hline
\end{tabular}

${ }^{a}$ Average of respondents who reported overtime.

b For 1996 and 1998 data only.

nonconstruction counterparts. This finding reflects the seasonal nature of construction jobs (table 2). In addition, construction workers spent more time on travel to their worksite than workers in other industries.

The number of workhours varied among the construction occupations and employment types (table 3). Self-employed workers typically worked more hours than wage and salary workers did. Among the production occupations, truck drivers, roofers, bricklayers, and construction laborers worked longer days than did workers in other construction trades.
Table 3. Distribution of hours worked per day by selected construction occupation and type of employment.

\begin{tabular}{lrrrrr}
\hline Category (N=size) & \multicolumn{5}{c}{ Hours worked per day } \\
\cline { 2 - 6 } & $\begin{array}{r}1-6 \\
(\%)\end{array}$ & $\begin{array}{r}7-8 \\
(\%)\end{array}$ & $\begin{array}{r}9-10 \\
(\%)\end{array}$ & $\begin{array}{r}11-12 \\
(\%)\end{array}$ & $\begin{array}{r}\geq 13 \\
(\%)\end{array}$ \\
\hline Occupations & & & & & \\
Professional \& managerial (354) & 6.5 & 41.1 & 38.5 & 7.0 & 6.9 \\
Clerical (155) & 18.1 & 58.0 & 20.2 & 3.7 & 0 \\
Bricklayer, mason (71) & 0 & 56.7 & 22.1 & 21.2 & 0 \\
Carpenter (380) & 3.9 & 58.5 & 30.3 & 5.8 & 1.5 \\
Electrical (137) & 0 & 81.4 & 16.5 & 0 & 0 \\
Painter (100) & 18.3 & 46.7 & 23.6 & 11.4 & 0 \\
Plumber (103) & 4.7 & 56.2 & 33.8 & 5.3 & 0 \\
Roofer (96) & 0 & 45.9 & 54.1 & 0 & 0 \\
Op engineer (182) & 0.6 & 70.9 & 18.2 & 10.4 & 0 \\
Truck driver (66) & 0 & 37.8 & 36.4 & 13.8 & 12.0 \\
Laborer \& helper (450) & 0.5 & 55.2 & 41.9 & 2.3 & 0 \\
Type of employment & & & & & \\
Self-employment (465) & 8.9 & 40.4 & 39.2 & 8.3 & 3.2 \\
Wage and salary (2067) & 3.1 & 56.2 & 32.8 & 5.9 & 1.8 \\
\hline
\end{tabular}

\section{Work-related injuries}

Construction workers had a higher work-related injury rate than did their nonconstruction counterparts. Approximately $11.5 \%$ of the NLSY79 respondents who worked in construction reported they had experienced a work-related injury since the previous interview, compared with $7.2 \%$ of the workers in other industries during the same period (OR 1.61, 95\% CI 1.60-1.62). However, the difference in the injury rates between the construction and nonconstruction workers within production occupations was relatively small $(11.8 \%$ versus $10.8 \%$, OR $1.09,95 \%$ CI 1.08-1.11). When the respondents with a work-related incident were asked about the results of that incident, only $2 \%$ of the construction workers reported an illness, while $8 \%$ of the nonconstruction workers did (OR 0.23 , 95\% CI 0.22-0.24); nearly all of the construction workers regarded their injury as severe, compared with $95 \%$ of the workers in other industries.

In construction, workers working $>8$ hours a day had higher injury rates than those who worked 7 or 8 hours a day $(15.0 \%$ versus $10.4 \%$, OR 1.57 , 95\% CI 1.56 1.58). Among the production workers in all industries, including the construction industry, the injury rate increased steadily along with the hours of overtime (figure 3 ). However, no such a trend was observed when the calculation was limited to the construction industry only. Perhaps the sample size of the construction workers was too small for a dose analysis.

Table 4 shows the results of the interaction analysis between overtime and work schedules in relation to workrelated injuries after control for industry, occupation, race, and gender. No interaction was observed between overtime and work schedules. However, shift work and time of starting or ending the workday significantly interacted. 


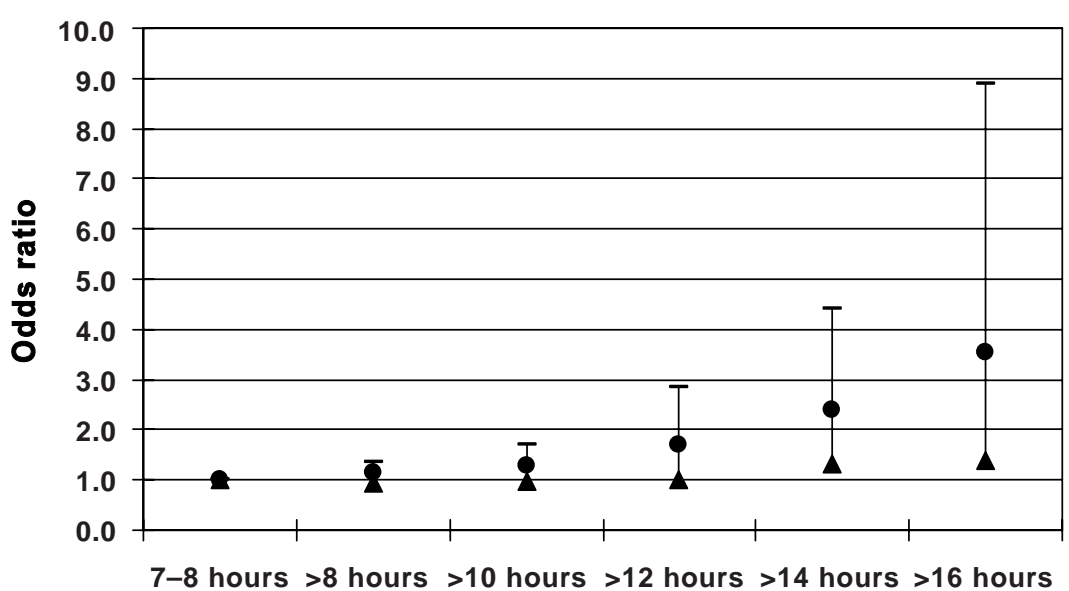

- Upper • 95\% CI $\triangle$ Lower
Figure 3. Most severe injury since workers' last interview. Overtime versus 7-8 hours. (1996 and 1998 surveys only; respondents who worked $<7$ hours per day were excluded; production occupations in all industries, $\mathrm{N}=4103$ )
Table 4. Interaction between overtime and work schedules in relation to work-related injuries (production occupations, $\mathrm{N}=4103$ ). (Multijob $=$ more than one job, shift $=$ not regular day shifts)

\begin{tabular}{|c|c|c|}
\hline Variables & F-value & P-value \\
\hline Early $\times$ shift ${ }^{a}$ & 17.36 & $<0.0001$ \\
\hline Overtime & 5.72 & 0.001 \\
\hline Shift & 5.60 & 0.017 \\
\hline Late $\times$ shift $^{b}$ & 3.99 & 0.046 \\
\hline Early & 3.98 & 0.048 \\
\hline Gender & 3.56 & 0.059 \\
\hline Late & 2.03 & 0.112 \\
\hline Overtime ${ }^{\mathrm{C}} \times$ industry & 1.74 & 0.187 \\
\hline Multijob & 1.46 & 0.227 \\
\hline Construction & 1.32 & 0.251 \\
\hline Overtime $\times$ shift & 0.52 & 0.470 \\
\hline Overtime $\times$ late & 0.42 & 0.517 \\
\hline Overtime $\times$ multijob & 0.08 & 0.716 \\
\hline Overtime $\times$ early & 0.01 & 0.916 \\
\hline
\end{tabular}

a Starting work before 0700 .

${ }^{b}$ Ending work after 2000.

c $>40$ hours per week.

Table 5 presents the results of the multiple-logistic regression model. The odds ratios indicate that similar increased risk factor effects occurred for the workers working longer hours, whether daily or weekly, after control for possible confounders. When workers worked $>40$ hours a week or 8 hours a day, the injury risk increased slightly. Above 50 hours a week, the risk was almost double (OR 1.98, 95\% CI 1.87-2.05). Moreover, shift work, multiple jobs, and starting work early or ending work late in the day were also associated with elevated injury rates.

\section{Discussion}

The results of this study support the hypothesis that the risk of injury increases along with long workhours,
Table 5. Risk factors for severe work-related injuries, production occupations ( $\mathrm{N}=4103)$. Variables with effects met the 0.05 significance level for entry into the model. The variables used that did not meet the criteria include hours worked at home, mileage, time traveling to work, and flexible schedule. Workers who usually worked $<7$ hours a day were excluded. $(0 \mathrm{R}=$ odds ratio, $95 \% \mathrm{Cl}=95 \%$ confidence interval)

\begin{tabular}{lccc}
\hline Risk factors & OR & $95 \% \mathrm{Cl}$ & P-value \\
\hline Weekly hours $>50$ & 1.98 & $1.88-2.05$ & 0.03 \\
Received overtime pay last week & 1.64 & $1.63-1.64$ & $<0.01$ \\
Overtime last week & 1.54 & $1.53-1.55$ & $<0.01$ \\
More than one job & 1.51 & $1.50-1.53$ & 0.02 \\
Started work before 0700 & 1.28 & $1.28-1.30$ & $<0.01$ \\
Shift work & 1.21 & $1.20-1.21$ & $<0.01$ \\
Construction & 1.19 & $1.18-1.19$ & $<0.01$ \\
Usual daily hours $>10$ & 1.18 & $1.17-1.19$ & $<0.01$ \\
Ended work after 2000 & 1.18 & $1.17-1.19$ & $<0.01$ \\
Male & 1.06 & $1.05-1.07$ & $<0.01$ \\
Self-employment & 1.03 & $1.02-1.04$ & $<0.01$ \\
Usual weekly hours $>40$ & 1.02 & $1.02-1.03$ & $<0.01$ \\
Usual daily hours $>8$ & 1.02 & $1.01-1.02$ & $<0.01$ \\
Nonwhite & 1.01 & $1.01-1.02$ & $<0.01$ \\
Age $>40$ years & 0.99 & $0.98-0.99$ & $<0.01$ \\
\hline
\end{tabular}

when other variables are held constant. Construction workers working long hours were significantly more likely to be involved in a work-related injury. The results also support the hypothesis that the work schedules of construction workers differ from those of workers in other industries. The construction workers started work earlier, worked longer days and fewer weeks, and were more likely to hold multiple jobs and change jobs than their nonconstruction counterparts. In addition, this study confirms previous findings that demographic and work-related factors affect worker safety $(27,28)$.

Although the NLSY is a unique source of information for studying the dynamics of work-related injuries and workhours longitudinally, this study has limitations stemming from the data source. First of all, it was not 
possible to verify the accuracy of the self-reported hours worked or to determine the day and at what time of the day each work-related injury occurred. Information about how long each day in a week people worked and how many days they worked per week is not available. The use of long recall periods and self-defined injuries may yield biased results (29). In addition, information on individual workloads and work conditions was not provided. Moreover, although the results showed that the risk of injury is associated with occupations, the sample size was too small to allow further analyses on detailed occupations. Thus the statistics may not sufficiently represent situations for certain construction occupations. Nonetheless, it is unlikely that there are other nationally representative sources of information on detailed work history and work-related injuries in the United States.

Despite the fact that an 8-hour workday has been widely established legally, the reality often differs. Data collected by the US Bureau of Labor Statistics reveal that the proportion of persons working very long workweeks has risen since the mid-1970s $(30,31)$. In addition, overtime may not always be reflected in official statistics (32). In construction, there are many circumstances (including project labor agreements in the US construction industry) that may result in $4 \times 10$-hour days or other variations of hours worked, which could not be considered overtime.

Whether long workhours adversely affect health has been debated for many years. The main argument advanced by people who advocate shorter hours is that work conditions are potentially injurious to workers' safety and health, particularly to those in hazardous occupations when long hours are worked, although researchers have not drawn a final conclusion $(3,15,20$, $21)$. Given the higher risk for long workhours in construction observed in this study, it is more likely the length and the other dimensions of workhours in construction that contribute to safety risks, rather than nightshift work, which has been the focus of most previous research (3-5).

Overtime is preferred by many people for cultural, social, and economic reasons. For instance, there is a prevailing, almost religious conviction of the virtues of hard work (33). The rising costs of health insurance, unemployment insurance, and government-mandated benefits have made paying overtime to current employees, rather than employing new ones, a relative bargain for employers (34). On the other hand, the preference for overtime seems to be coming from employees themselves. A survey conducted by the Cornell University indicates that job insecurity and financial strain are significantly correlated with workers' preference for overtime (35). From a worker's perspective, working in the construction industry is relatively contingent. No one knows how long any given job will last; therefore, when a worker has a job, he or she has to work as much as possible. This is the nature of the construction industry.

Overtime is also a result of the popular misconception that longer hours mean higher productivity. Actually, increased workhours neither necessarily lead to a rise in output nor decreased hours to curtailed output. Instead, a shortening of the workweek below, or a lengthening of the workweek above, a maximum output point may lead to a decline in output (36). A study of overtime and productivity in electrical construction found that the use of overtime is generally acknowledged to present significant cost increases (37).

Overtime may be necessitated by poor organizational and managerial practices, such as a lack of proper planning, unrealistic work schedules, or orders to redo work. Construction project owners and contractors need to use more careful planning, staffing, and training to set appropriate work schedules and cut unnecessary overtime. If workers sometimes have to work overtime and irregular work schedules, especially continually long workdays, it may be advisable to provide more onsite breaks during workdays. In addition, because of the highly skilled character of the work in some construction occupations, it is necessary to have a sufficiently large trained workforce in place to meet demand in times of peak economic activity.

The results of this study may also suggest a need for public policy intervention, such as establishing a ceiling for workhours during a certain time period in construction and other industries in similar situations. From a safety and health perspective, limiting the acceptable hours of work makes sense, especially for workers in high-risk occupations. Such a limitation may even be an economically sound approach if the costs of workrelated injuries and illnesses are taken into account, even without the possible negative effects of overtime on productivity being considered.

The results of this study, however, need confirmation in additional studies. Regarding the interaction between hours at work and other hazards in the workplace, it would be meaningful to develop more adequate exposure models to arrive at more reliable estimates. Nonetheless, for additional studies, adequate databases to estimate the exposure would be urgently needed.

\section{Acknowledgments}

This project was made possible by grant CCU317202 from the US National Institute for Occupational Safety and Health (NIOSH). The contents are solely the responsibility of the author and do not necessarily represent the official views of NIOSH. 
The author thanks Pete Stafford, Jane Seegal, and Pamela Entzel for their comments and help.

\section{References}

1. Martens, MFJ. Flexible work schedules and mental and physical health: a study of a working population with non-traditional working hours. J Organ Behav 1999;20(1):35-46.

2. Harrington JM. Shift work and health-a critical review of the literature on working hours. Ann Acad Med 1994; 23(5):699-705.

3. Smith L, Folkard S, Tucker P, Macdonald I. Work shift duration: a review comparing eight hour and 12 hour shift systems. Occup Environ Med 1998;55(4):217-29.

4. Frank AL. Injury related to shiftwork. Am J Prev Med 2000; 18(4):33-6.

5. Rosa RR. Extended workshifts and excessive fatigue. J Sleep Res 1995;4(20):51-6.

6. Duchon C, Smith TJ. Extended workdays and safety, Intern J Ind Ergon 1993;11:37-49.

7. Borg V, Kristensen TS. Psychosocial work environment and mental health among traveling salespeople. Work Stress 1999;13(2):132-43.

8. Lusardi P, Zoppi A, Preti P, Pesce RM, Piazza E, Fogari R. Effects of insufficient sleep on blood pressure in hypertensive patients: a 24-h study. Am J Hypertens 1999;12:63-8.

9. Spiegel K, Leproult R, Van Cauter E. Impact of sleep debt on metabolic and endocrine function. Lancet 1999;354:1435-9.

10. Park J, Kim Y, Cho Y, Woo KH, Chung HK, Iwasaki K, et al. Regular overtime and cardiovascular functions. Ind Health 2001;39(3):244-9.

11. Trinkoff AM, Storr CL. Work schedule characteristics and substance use in nurses. Am J Ind Med 1998;34 (3):266-71.

12. Nakamura K, Shimai S, Kikichi S, Takahashi H, Tanaka M, Nakano S, et al. Increase in body mass index and waist circumference as outcomes of working overtime. Occup Med 1998;48:169-73.

13. Daltroy LH, Larson MG, Wright EA, Malspeis S, Fossel AH, Ryan J, et al. A case-control study of risk factors for industrial low back injury: implications for primary and secondary prevention programs. Am J Ind Med 1991;20(4):505-15.

14. Waersted M, Westaard RH. Working hours as a risk factor in the development of musculoskeletal complaints. Ergonomics 1991;34(3):265-76.

15. Shields M. Long working hours and health. Health Rep 1999; 11:33-48.

16. Ono Y, Watanabe S, Kaneko S, Matsumoto K, Miyao M. Working hours and fatigue of Japanese flight attendants. J Hum Ergol (Tokyo) 1991;20(2):155-64.

17. Park J, Kim Y, Chung HK, Hisanaga N. Long working hours and subjective fatigue symptoms. Ind Health 2001;39(3):250 4.

18. Hänecke, K, Tiedmann, S, Nachreiner F, Grzech-Šukal. Accident risk as a function of hour at work and time of day as determined from accident data and exposure models for the German working population. Scand J Work Environ Health 1998;24 suppl 3:43-8.

19. Nylén L, Voss M, Floderus B. Mortality among women and men relative to unemployment tome work, overtime work, and extra work: a study based on data from the Swedish twin registry. Occup Environ Med 2001;58:52.

20. van der Hulst M. Long workhours and health [review]. Scand J Work Environ Health 2003;29(3):171-88.

21. Caruso CC, Hitchcock EM, Dick RB, Russo JM, Schmit JM. Overtime and extended work shifts: recent findings on illnesses, injuries, and health behaviors. Washington (DC): US Department of Health and Human Services, Centers for Disease Control and Prevention, National Institute for Occupational Safety and Health (NIOSH); 2004. DHHS (NIOSH), report no 143.

22. Ringen K, Englund A, Welch L, Weeks JL, Seegal JL. Perspectives on the future. Occup Med 1995;10(2):445-51.

23. Thomas HR. Effect of scheduled overtime on labor productivity. J Constr Eng Manage 1992;118(2):60-76.

24. Lowery JT, Borgerding JA, Zhen B, Glazner JE, Bondy J, Kreiss K. Risk factors for injury among construction workers at Denver International Airport. Am J Ind Med 1998;34:11320.

25. Goldhenhar LM, Hecker S, Moir S, Rosecrance J. The "Goldilocks model" of overtime in construction: not too much, not too little, but just right. J Saf Res 2003;34:215-26.

26. Defense Manpower Data Center. NLSY79 main file codebook attachments and appendices, attachment 3: 1970 \& 1980 census industrial \& occupational classification codes and 1977 department of defense enlisted occupational codes. Alexandria (VA): Defense Manpower Data Center; 1970. Cited January 2004; available at: http://www.bls.gov/nls/79quex/r19/ y79r19attach3.pdf

27. Ettner SL. Grzywacz JG. Workers' perceptions of how jobs affect health: a social ecological perspective. J Occup Health Psychol 2001;6(2):101-13.

28. Dembe A, Erickson J, Delbos R. Predictors of work-related injuries and illnesses: national survey findings. J Occup Environ Hyg 2004:1(8):542-50.

29. Veazie MA. Heavy drinking, alcoholism, and injuries at work [dissertation]. Baltimore (MD): Johns Hopkins University; 1994.

30. Rones PL. Trends in hours of work since the mid-1970s. Mon Labor Rev 1997;April:3-14.

31. US General Accounting Office (GAO). Fair labor standard act: white collar exemptions in the modern work place: report to the Subcommittee on Workforce Protections, Committee on Education and the Workforce, US House of Representatives. Washington (DC): General Accounting Office; 1999. Report no GAO/HEHS-99-164.

32. Worth R. Exhaustion that kills: medical residents in New York City. Wash Mon 1999;31:15-20.

33. Marshall FR, Briggs VM, Vernor MB, King AG Jr. Labor economics: wages, employment, trade unionism, and public policy. 5th ed. Homewood (IL): RD Irwin; 1984. p 520.

34. Fisher AB. Welcome to the age of overwork, managers. Fortune 1992;126:64-7.

35. Cornell University. Overtime and the American workers. New York (NY): New York State School of Industrial and Labor Relations; 1999.

36. Thomas HR, Raynar KA. Scheduled overtime and labor productivity: quantitative analysis. J Constr Eng Manage 1997;123(1):181-8.

37. National Electrical Contractors Association. Overtime and productivity in electrical construction. Bethesda (MD): National Electrical Contractors Association; 1989. p 1-36.

Received for publication: 26 November 2004 